\title{
TSST-1, enterotoxin and bacteriocin-like substance production by Staphylococcus aureus isolated from foods
}

[TSST-1, enterotoxinas e substâncias tipo bacteriocina produzidas por

Staphylococcus aureus isolados de alimentos]

\author{
S.A. Carvalho ${ }^{1}$, L.S. Carmo $^{2}$, E.F. Abreu ${ }^{1}$, R.S. Dias ${ }^{2}$, A.C.M. Apolônio ${ }^{1}$, S.G. Santos ${ }^{1}$, \\ L.M. Farias ${ }^{1}$, M.A.R. Carvalho ${ }^{1} *$ \\ ${ }^{1}$ Instituto de Ciências Biológicas - Universidade Federal de Minas Gerais - Belo Horizonte, MG \\ ${ }^{2}$ Fundação Ezequiel Dias - Belo Horizonte, MG
}

\begin{abstract}
The production of Toxic Shock Syndrome Toxin-1 (TSST-1), enterotoxins and bacteriocin-like substances was evaluated in 95 strains of Staphylococcus aureus recovered from raw bovine milk $(\mathrm{n}=31)$ and from food samples involved in staphylococcal food poisoning $(n=64)$. Enterotoxigenicity tests with the membrane over agar associated to optimal sensibility plate assays were performed and showed that $96.77 \%$ of strains recovered from milk and $95.31 \%$ from food samples produced enterotoxins A, B, C, D or TSST-1. Reference strains $S$. epidermidis, Bacillus cereus, Listeria monocytogenes, Lactobacillus casei, Pseudomonas aeruginosa, S. aureus, Salmonella Typhimurium, Escherichia coli, Enterococcus faecalis and Bacteroides fragilis were used as indicator bacteria in the antagonistic assays, the first five being sensitive to antagonistic substances. Brain heart infusion agar, in $\mathrm{pH}$ values ranging from 5.0 to 7.0 in aerobic atmosphere showed to be the optimum condition for antagonistic activity as evaluated with the best producer strains against the most sensitive indicator bacterium, L. monocytogenes. Sensitivity to enzymes confirmed the proteinaceous nature of these substances. Neither bacteriophage activity nor fatty acids were detected and the antagonistic activity was not due to residual chloroform. Results did not establish a positive correlation between the bacteriocinogenic profile and toxigenicity in the tested $S$. aureus strains.
\end{abstract}

Keywords: Cattle, mastitis, toxigenicity, food poisoning, bacteriocin

\section{RESUMO}

Avaliou-se a produção de toxina-1 da síndrome do choque tóxico (TSST-1), enterotoxinas e substâncias antagonistas tipo bacteriocina em 95 amostras de Staphylococcus aureus recuperadas de leite bovino in natura $(n=31)$ e de alimentos envolvidos em surto de intoxicação $(n=64)$. Testes de enterotoxigenicidade pelo método da membrana sobre ágar, associado à técnica da sensibilidade ótima em placa, revelaram que 96,77\% das amostras do leite e 95,31\% daquelas dos alimentos produziram enterotoxinas estafilocócicas tipos $A, B, C, D$ ou TSST-1. Nos ensaios de antagonismo, foram utilizadas como reveladoras amostras de referência de S. epidermidis, Bacillus cereus, Listeria monocytogenes, Lactobacillus casei, Pseudomonas aeruginosa, S. aureus, Salmonella typhimurium, Escherichia coli, Enterococcus faecalis $e$ Bacteroides fragilis, sendo as cinco primeiras sensíveis às substâncias produzidas. As condições ótimas para a atividade antagonista, avaliadas com as melhores produtoras contra a indicadora mais sensivel, L. monocytogenes, foram observadas em aerobiose, em ágar infuso de cérebro-coração, nos valores de pH entre 5,0 e 7,0. A sensibilidade a enzimas confirmou a natureza proteica destas substâncias. Não foram detectadas atividades de bacteriófagos nem de ácidos graxos, e a atividade antagonista não foi devido ao clorofórmio residual. Os resultados não mostraram correlação entre o perfil bacteriocinogênico e a toxigenicidade nas amostras de Staphylococcus testadas.

Palavras-chave: bovinos, mastite, toxigenicidade, intoxicação alimentar, bacteriocina

Recebido em 16 de setembro de 2012

Aceito em 8 de maio de 2013

*Autor para correspondência (corresponding author)

E-mail: marc@icb.ufmg.br 


\section{INTRODUCTION}

Staphylococcus is a genus of Gram-positive bacteria that can be found as indigenous microbiota of mammals, but can also survive in a variety of environments and survive desiccation (drying). There are over 30 recognized species of staphylococci, and $S$. aureus is considered the most pathogenic one for humans and other animals. Meticillin-resistant S. aureus (MRSA) has a particular Public Health significance for both human and veterinary medicine, but also in food microbiology. MRSA clones have originated in at least three separate settings: human hospitals, human carriers outside of hospitals (community), and livestock animals (The EFSA Journal, 2009). Due to its ability to colonize a wide range of species, $S$. aureus can be readily transmitted from one species to another, including from humans to other animals and vice versa.

It has been considered that 3 percent of all animals are infected with $S$. aureus (Schukken et al., 2009). It causes food poisoning (Carmo et al., 2004; Borelli et al., 2011) and it is the most common mastitis etiologic agent, which is the main dairy cattle disease (Fagundes et al. 2010). $S$. aureus represents 10 to 12 percent of all clinical mastitis infections (Schukken et al., 2009).

Toxin-1 that causes Toxic Shock Syndrome in humans (TSST-1) and staphylococcal enterotoxins (SEs) play an important role in staphylococcal diseases (Robert et al., 2011). Though data are limited, reports show that producing strains of these toxins isolated from foods should be better evaluated (Tasci et al., 2011).

Bacteriocins are proteinaceous antimicrobial substances produced by bacteria and thus it is expected that they have an ecological role. Many bacteriocins from Gram-positive bacteria have fairly broad inhibitory spectra, and this property might be explored as potentially useful when considering food preservation or even alternative therapeutic agents (Gálvez et al., 2007). Bacteriocin production has been studied in different groups of bacteria, including staphylococci (Bali et al., 2011; Chehimi et al., 2012).
There is no doubt that milk is an inevitable part of the human diet, especially raw milk from cattle in most developing countries, requiring strict sanitary control. Considering the metabolic potential of $S$. aureus, this paper reports the production of bacteriocin-like substances and toxigenicity of strains isolated from foods and evaluates their possible correlation.

\section{MATERIALS AND METHODS}

A total of 95 Staphylococcus aureus strains from culture collection of the Laboratório de Microbiologia de Alimentos in Fundação Ezequiel Dias were tested. Thirty-one of them were recovered from bovine raw milk, which was clandestinely commercialized in the municipality of Betim and Nova Serrana in Minas Gerais State, Brazil. The remaining 64 strains were isolated from foods (rice, beans, cooked bovine meat and chicken with a pile of manioc flour fried with bacon, boiled egg chunks, green olives, and others) involved in foodborne diseases occurred on July 28, 1998 in the municipality of Santana do Manhuaçu in Minas Gerais State. This event culminates in 396 hospitalized patients with 16 deaths. Mortality occurred only in the oldest (65 and above) and youngest ( 5 and under) members of this population. The microorganisms were identified by conventional biochemical tests, in the Microbiologia de Alimentos and Enterotoxinas laboratories at FUNED. The tests included coagulase, termonuclease and catalase production, haemolytic hability and glucose and mannitol fermentation.

TSST-1 and enterotoxins production were produced by membrane-over-agar technique as described by Hallender (1965), with modifications. The supernatants obtained from each culture were tested by immunodifusion using the optimum-sensitivity plate method (OSP) (Robbins et al., 1974). After an incubation period of 24 hours at $37^{\circ} \mathrm{C}$ in a humid chamber, the plates were examined for precipitin lines of identity with the standards.

Ten reference strains of Staphylococcus epidermidis (ATCC 12228), Bacillus cereus (ATCC 11778), Listeria monocytogenes (ATCC 15313), Lactobacillus casei (ATCC 7469), Pseudomonas aeruginosa (ATCC 10145), Staphylococcus aureus (ATCC 12600), Salmonella 
Typhimurium (ATCC14028), Escherichia coli (ATCC 11775), Enterococcus faecalis (ATCC 19433) and Bacteroides fragilis (ATCC 25285) were used as indicators in the double layer method (Kelner, 1948).

The best four strains $(5 \mathrm{~L}, 12 \mathrm{~L}, 28 \mathrm{~L}$ and $31 \mathrm{~L}$, called test-strains) which showed inhibitory activity against the most sensitive indicator bacterium, L. monocytogenes ATCC 15313 were tested for influence of culture media, $\mathrm{pH}$ and atmosphere incubation conditions.

To evaluate culture media composition influence of inhibitory activity, $S$. aureus were cultivated in BHI broth (Difco Laboratories, Sparks, $\mathrm{MD}$, USA), at $37^{\circ} \mathrm{C}$, for 24 hours under anaerobic atmosphere (anaerobic chamber; Forma Scientific Company, Marietta, OH, USA, containing an atmosphere of $85 \% \mathrm{~N}_{2}, 10 \% \mathrm{H}_{2}$ and $5 \% \mathrm{CO}_{2}$ ). The cultures were spotted with a Steers' replicator onto the surface of BHI agar and Trypticase Soy Agar (TSA) (Difco) in $\mathrm{pH}$ 7.0. After incubation, test-strains were killed with chloroform vapor for 30 minutes. After the evaporation of residual chloroform, each plate was overlaid with $9.0 \mathrm{~mL}$ of semisolid agar BHI $(0.7 \% \mathrm{w} / \mathrm{v})$, containing approximately $10^{6}$ cells $/ \mathrm{mL}$ of indicator bacterium. Plates were then incubated for an additional $24-48 \mathrm{~h}$ period, at $37^{\circ} \mathrm{C}$, under the appropriate atmosphere according to the indicator strain, and evaluated for the presence of growth inhibition zone. The experiments were performed in duplicate and repeated at least once. The influence of $\mathrm{pH}$ on antimicrobial activity was evaluated in BHI agar, at different $\mathrm{pH}$ values $(4.0,5.0,6.0,6.6,7.0,8.0$, $9.0,10.0,11.0,12.0$ ) also using the double layer method. The influence of the atmosphere on antagonistic substance production was evaluated cultivating the producers on $\mathrm{BHI}$ agar, at selected $\mathrm{pH}$ values (5.0 and 6.6) on aerobic, anaerobic and microaerophilic (candle jar) atmospheres, at $37^{\circ} \mathrm{C}$, for $24 \mathrm{~h}$. The antagonistic activity was determined as described previously.

The detection of interfering factors was performed. To exclude the eventual presence of bacteriophages, a piece $(3 \mathrm{~mm}$ in diameter) of agar derived by inhibition area, was aseptically taken and placed over BHI agar plate. It was immediately recovered with semisolid BHI containing standard indicator bacterium aliquot. After a $24 \mathrm{~h}$ incubation at $37^{\circ} \mathrm{C}$, lytic zones were examined. To exclude the possibility of inhibition by long-chain fatty acids, tests were conducted on BHI agar, with and without the addition of $1 \%$ soluble starch (Walstad et al., 1974). To exclude acidic $\mathrm{pH}$ as being responsible for antagonism, the $\mathrm{pH}$ inside and outside the inhibition zone medium was measured with a microeletrode (Microeletrode Inc., foster City, CA, USA). The obtained values were compared with those measured on control-plates, without bacterium inoculum. Finally, to exclude a possible interference of residual chloroform on the growth of indicator strains, after the growth of the producers, the indicator sensitive strain was inoculated with a loop near the spots of the producers (BHI agar at $\mathrm{pH} 5.0$ and 6.6), but without contacting them (Apolônio et al., 2007). After 24 hours at $37^{\circ} \mathrm{C}$ on aerobic atmosphere, plates were observed for the presence of inhibition zones around the spots of producer strains.

To determine the biochemical nature of antimicrobial compounds, $50 \mu \mathrm{L}$ enzyme aliquots trypsin E.C. 3.4.21.4 type VIII (SIGMA), proteinase $\mathrm{K}$ (GIBCO-BRL) and papain E.C. 3.4.22.2 (SIGMA) were added around spots of the test-strains growth on incubation conditions described above. The plates were incubated for one hour, under aerobic atmosphere, at $37^{\circ} \mathrm{C}$. After this period the double layer technique was performed to evaluate eventual degradation of the antagonistic substance.

\section{RESULTS AND DISCUSSION}

Almost all S. aureus strains randomly selected from raw milk $(96.77 \%)$ and food poisoning samples (95.31\%) were enterotoxins A, B, C, D and TSST-1 producers. Among all toxins studied here, TSST-1 and SEB showed a broader occurrence, $27(87.10 \%)$ from food samples and 22 strains from milk $(70.97 \%)$. The most detected enterotoxin from food poisoning strains was SEB (Figure 1). 


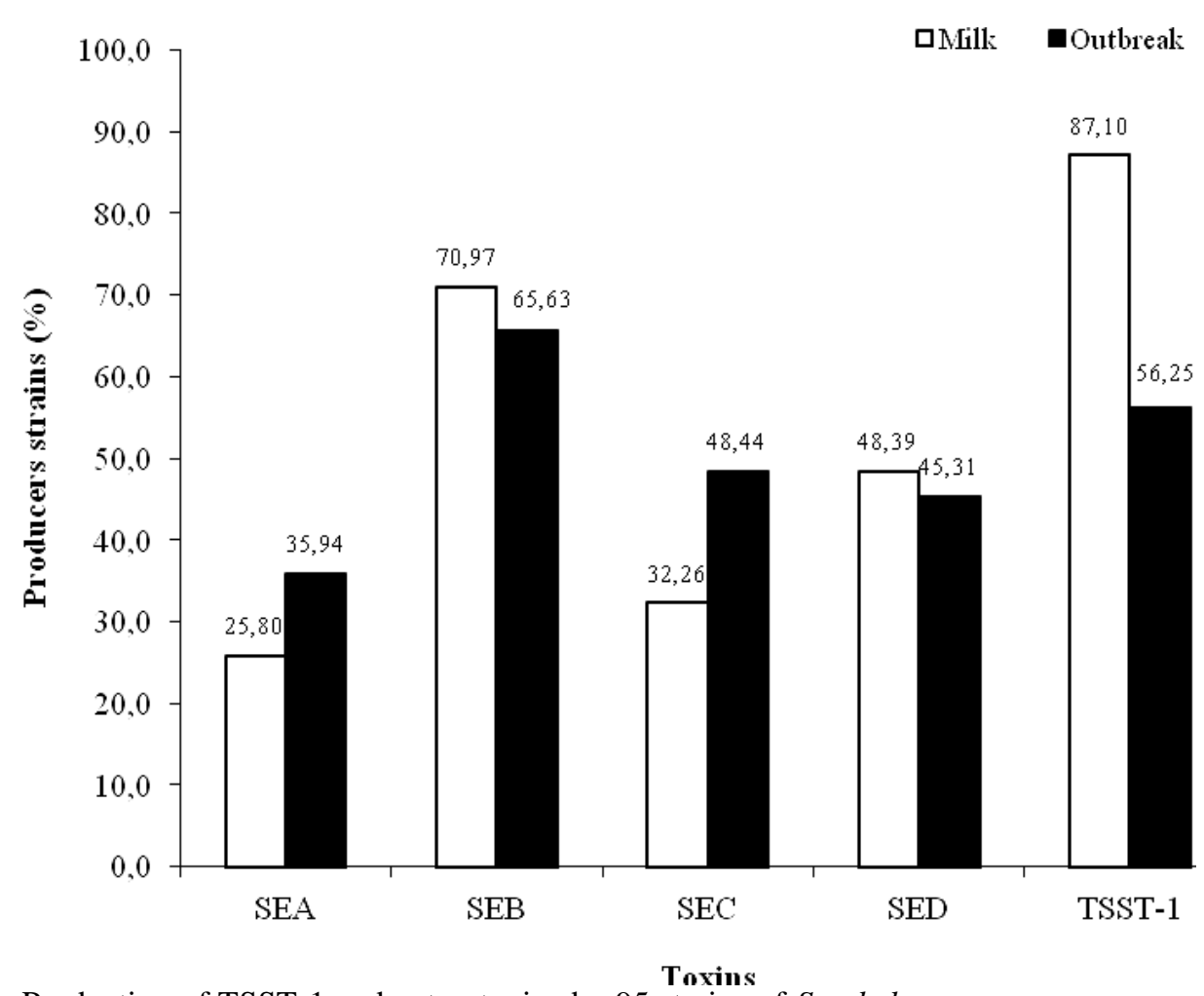

Figure 1. Production of TSST-1 and enterotoxins by 95 strains of Staphylococcus aureus recovered from bovine raw milk $(n=31)$ and food samples involved in staphylococcal outbreak $(n=64)$.

Only S. epidermidis (ATCC 12228), B. cereus (ATCC 11778), L. monocytogenes (ATCC 15313), L. casei (ATCC 7469) and P. aeruginosa (ATCC 10145) proved to be susceptible to antagonistic substances produced by at least one of the $S$. aureus strains (Tab. 1). $L$. monocytogenes was the most susceptible indicator strain and it is interesting to point out that $B$. fragilis showed more exuberant growth around $S$. aureus spots (data not shown).

The best culture condition for antimicrobial substance production was BHI agar medium at $\mathrm{pH}$ ranging from 5.0 to 7.0 in aerobic atmosphere.

Bacteriophages were not found in the inhibition zones. In addition, chloroform was not able to inhibit the indicator strain (L. monocytogenes) and no significant variations in $\mathrm{pH}$ values were detected inside and outside the inhibition zones, as well as in the noninoculated medium.
The inhibitory substances were susceptible only to trypsin and proteinase $\mathrm{K}$.

In all tests performed using Lactobacillus casei as indicator strain the presence of a hazy zone around the growth spot was observed. The same phenomenon was observed with $P$. aeruginosa, making the interpretation difficult.

Inhibition zones produced by strains of $S$. aureus recovered from raw bovine milk were larger and clearer than those inhibition zones produced by strains of $S$. aureus recovered from food samples involved in food poisoning outbreak (data not shown). However, in general, the antimicrobial substances produced by $S$. aureus strains recovered from foods showed good stability in a broad range of $\mathrm{pH}$ values (from 5.0 to 11.0), although the results indicate that the most effective production was observed at $\mathrm{pH}$ values near 7.0. 
Table 1. Antimicrobial spectrum of the antagonistic substances produced by S.aureus recovered from bovine raw milk $(n=31)$ and food samples involved in staphylococcal food poisoning $(n=64)$, using ten reference strains as indicators - S. aureus (ATCC 12600), S. epidermidis (ATCC 12228), L. monocytogenes (ATCC 15313), B. cereus (ATCC 11778), L. casei (ATCC 7469), E. faecalis (ATCC 13433), E. coli (ATCC 11775), P. aeruginosa (ATCC 10145), S. Typhimurium (ATCC 14028) and $B$. fragilis (ATCC 25285), on BHI agar, $\mathrm{pH} \mathrm{7.0,} \mathrm{at} 37^{\circ} \mathrm{C}$.

\begin{tabular}{lcc}
\hline \multirow{2}{*}{ Indicator strains } & \multicolumn{2}{c}{$\begin{array}{c}\text { No of producers strains } \\
\text { Total of strains }\end{array}$} \\
\cline { 2 - 3 } Staphylococcus aureus (ATCC 12600) & Raw milk & Outbreak \\
Staphylococcuus epidermidis (ATCC 12228) & $1^{\mathrm{h}} / 31$ & $0 / 64$ \\
Listeria monocytogenes (ATCC 15313) & $4^{\mathrm{c}} / 31$ & $0 / 64$ \\
Bacillus cereus (ATCC 11778) & $2^{\mathrm{r}} / 31$ & $0 / 64$ \\
Lactobacillus casei (ATCC 7469) & $4^{\mathrm{h}} / 31$ & $0 / 64$ \\
Enterococcus faecalis (ATCC 13433) & $0 / 31$ & $8^{\mathrm{h}} / 64$ \\
Escherichia coli (ATCC 11775) & $0 / 31$ & $0 / 64$ \\
Pseudomonas aeruginosa (ATCC 10145) & $29^{\mathrm{h}} / 31$ & $0 / 64$ \\
Salmonella Typhimurium (ATCC 14028) & $0 / 31$ & $60^{\mathrm{h}} / 64$ \\
Bacteroides fragilis (ATCC 25285) & $0 / 31$ & $0 / 64$ \\
\hline h= hazy zone; co clear zone; $\mathrm{r}=$ resistent clones & & $0 / 64$ \\
\hline
\end{tabular}

The prevalence of enterotoxin producing strains among $S$. aureus recovered from raw milk was higher than those reported in literature (Fagundes et al., 2010; Neder et al., 2011), although enterotoxin genes have already been reported in $93.6 \%$ of $S$. aureus strains isolated from milk of cows with mastitis (Srinivasan et al., 2006). Besides, the co-production of TSST-1 and enterotoxins seem to be widespread (Fagundes et al., 2010).

It should be emphasized that raw milk samples analyzed for the presence of enterotoxigenic strains in this study came from small farms in Minas Gerais State. These results are indicative of no mastitis control in herds. According to Peles and collaborators (2007) farms with a large number of cows with mastitis by $S$. aureus may contaminate bulk milk and, subsequently, raw milk products.

Literature reports high variability in the enterotoxigenic strains (range from 0 to $51.7 \%$ ) isolated from cows presenting mastitis (Cunha et al., 2007). Takeuchi et al. (1998) showed high percentages of TSST-1 produced by strains of Staphylococcus isolated from cows presenting subclinical mastitis (76.7\%), farm bulk milk $(75.4 \%)$ and clinical mastitis $(58.1 \%)$. They found TSST-1 produced by $S$. aureus strain isolated from animals with high rates of SEB and SED detection and also a low frequency of SEA. On the other hand, Zschock et al. (2004) reported sec/tst gene positive $S$. aureus in clinical isolates from bovine mastitis. They observed occurrence and clonal relatedness of sec/tst gene positive $S$. aureus isolates from quartermilk samples of cows suffering from mastitis.

The high percentage of toxigenic strains recovered from food poisoning highlights the importance of carriers in the epidemiology of staphylococcal outbreaks. The high prevalence of SEB detected in this study corroborates data observed by $\mathrm{Ng}$ and Tay (1993) analyzing readyto-use food and drink, which showed a high percentage of SEB producer strains. It should be pointed out that data obtained in this study are different from the majority observed in the literature, which shows SEA as a most frequently detected enterotoxin (Dinges et al., 2000).

The fact that almost all isolates of Staphylococcus aureus studied were toxin 
producers indicates its importance as a food poisoning source, requiring a better food quality control (Cretenet et al., 2011).

The antimicrobial spectrum of the antagonistic substances produced by $S$. aureus strains recovered from food seems to be narrow, as observed for the classical bacteriocins (Héchard and Sahl, 2002). Under this concept, bacteriocins are proteins produced by bacteria with a narrow spectrum of antagonistic activity against related species. The inhibition of Listeria monocytogenes by $S$. aureus had already been reported by Oliveira and coworkers (1998) and Ceotto et al. (2009). Bacterial interactions, including synergism and commensalism, beyond antagonism are likely to play an important role in the ecology of the microbiota. The Bacteroides fragilis growth zones around $S$. aureus spots suggest that these bacteria probably released some substance that favoured $B$. fragilis growth.

Despite the data available in literature indicating that the production of antagonistic substances occurred preferably in a stressful environment (Verluyten et al., 2004), the results obtained here do not corroborate those findings. Our data show that the rich medium Brain Heart Infusion agar seems to be the most proper to assay the production of antagonistic substances by Staphylococcus aureus, which is in accordance to results reported by Oliveira et al. (1998). These authors also found Brain Heart Infusion agar to be the best medium for antagonistic substance production by $S$. aureus strains and not the nutritionally poor Triptic Soy Agar medium.

The presence of a hazy zone of inhibition of Lactobacullus casei indicator strain around the growth of $S$. aureus suggests a weak inhibitory activity of antagonistic substances produced by $S$. aureus against $L$. casei. This bacterium belongs to the lactic acid bacteria group, and is a classical well known competitor of $S$. aureus since it produces a large quantity of bacteriocins (Bali et al., 2011).

It should be pointed out that Listeria monocytogenes growth inhibition by strains of $S$. aureus is very relevant since $L$. monocytogenes is a putative causal agent of mastitis and a severe human pathogen (Nightingale et al., 2004). Thus, the detection of $S$. aureus antagonistic substances producer opened novel applications for these substances such as food preservatives, especially in cheese, milk and fish industries (Nascimento et al., 2005). This bacterial product, an antimicrobial agent in potential, could also be useful as a biotechnological tool to control mastitis.

In vitro stability of antimicrobial substances produced by $S$. aureus in a large range of $\mathrm{pH}$ values suggests that these substances should play an ecological role in vitro as well as in vivo.

The antagonism observed here for $S$. aureus isolates was not due to chloroform action, bacteriophage or acidic $\mathrm{pH}$, as demonstrated by the experiments on interference factors. The proteinaceous nature of these substances was confirmed by the loss of activity in the presence of proteolytic enzymes, such as trypsin and proteinase $\mathrm{K}$. The non-susceptibility of the antagonistic substances to papain could indicate that these substances cannot be blocked in susceptible cell surface receptors, and thus contribute to its effectiveness.

Reports on simultaneous production of bacteriocins and enterotoxins by $S$. aureus were not found in literature. In this study, no particular association between toxigenicity and bacteriocinogenicity could be established considering the tested strains. Moreover, large intra-specific variation of these two properties was found among the isolates. It is possible that the evaluation of a more representative sample and the addition of molecular parameters, besides in vivo studies, may reveal eventual associations of ecological and epidemiological interest.

\section{CONCLUSIONS}

The high percentage of toxigenic strains recovered from raw bovine milk and food poisoning highlights the importance of carriers in the epidemiology of staphylococcal outbreaks. Although the antimicrobial spectrum of the antagonistic substances produced by $S$. aureus strains recovered from raw bovine milk and food seems to be narrow, the effects against Listeria monocytogenes suggest this property as potentially useful when considering food preservation or even alternative therapeutic agents. No particular association between 
toxigenicity and bacteriocinogenicity could be established considering the tested strains.

\section{ACKNOWLEDGMENTS}

The technical assistance of Luzia Rosa Resende is gratefully acknowledged. The authors thank Dr. Mônica Maria Oliveira Pinho Cerqueira for kindly revising this paper. This work was supported by Conselho Nacional de Desenvolvimento Científico e Tecnológico (CNPq), Fundação de Amparo à Pesquisa de Minas Gerais (FAPEMIG), Coordenação de Aperfeiçoamento de Pessoal de Nível Superior (CAPES) and Pró-Reitoria de Pesquisa da Universidade Federal de Minas Gerais (PRPq/UFMG).

\section{REFERENCES}

APOLÔNIO, A.C.M.; CARVALHO, M.A.R.; RIBAS, R.N.R. et al. Production of antagonistic substance by Eikenella corrodens isolated from the oral cavity of human beings with and without periodontal disease. J. Appl. Microbiol., v.103, p.245-251, 2007.

BALI, V.; PANESAR, P.S.; BERA, M.B. Isolation, screening and evaluation of antimicrobial activity of potential bacteriocin production lactic acid bacteria isolate. Microbiol. J., v.1, p.113-119, 2011.

BORELLI, B.M.; LACERDA, I.C.A.; BRANDÃO, L.R. et al. Staphylococcus spp. isolated during the ripening process of a traditional Minas cheese. Arq. Bras. Med. Vet. Zootec., v.63, p.481-487, 2011.

CARMO, L.S.; CUMMINGS, C.; LINARDI, V.R. et al. A case study of a massive staphylococcal food poisoning incident. Foodborne Pathog. Dis., v.1, p.241-246, 2004.

CEOTTO, H.; NASCIMENTO, J.S.; BRITTO, M.A. et al. Bacteriocin production by Staphylococcus aureus involved in bovine mastitis in Brazil. Res. Microbiol., v.160, p.592599, 2009.

CHEHIMI, S.; LIMAM, F.; LANEELUC, I. et al. Identification of Three Novel B. thuringiensis Strains that Produce the Thuricin S bacteriocin. Bt. Research., v.3, p.3-10, 2012.
CRETENET, M.; EVEN, S.; LE LOUIR, Y. Unveiling Staphylococcus aureus enterotoxin production in dairy products: a review of recent advances to face new challenges. Dairy Sci.\& Technol., v.91, p.127-150, 2011.

CUNHA, M.L.; CALSOLARI, R.A.; JUNIOR, J.P. Detection of enterotoxin and toxic shock syndrome toxin 1 genes in by PCR and RPLA assay. Microbiol. Immun., v.51, p.381-390, 2007.

DINGES, M.M.; ORWIN, P.M.; SCHLIEVERT, P.M. Exotoxins of Staphylococcus aureus. Clin. Microbiol. Rev., v.13, p.16-34, 2000.

FAGUNDES, H.; BARCHESI, L.; FILHO, A.N. et al. Occurrence of Staphylococcus aureus in raw milk produced in dairy farms in São Paulo. Brazilian J. Microbiol., v.41, p.376-380, 2010.

GÁLVEZ, A.; ABRIOUEL, H.; LÓPEZ, R.L.; BEN OMAR, N. Bacteriocin-based strategies for food biopreservation. Int. J. Food Microbiol., v.120, p.51-70, 2007.

HALLANDER, H.O. Production of large quantities of enterotoxin $B$ and other staphylococcal toxins on solid media. Acta Pathol. Microbiol. Scand., v.63, p.299-305, 1965.

HÉCHARD, Y.; SAHL, G.H. Mode of action of modified and unmodified bacteriocins from Gram-positive bacteria. Biochimie, v.84, p.545557, 2002.

KELNER, A.A method for investigating large microbial population for antibiotic activity. $J$. Bacteriol., v.56, p.157- 162, 1948.

NASCIMENTO, J.S.; FAGUNDES, P.C.; BRITO, M.A.V.P. et al. Production of bacteriocins by coagulase-negative staphylococci involved in bovine mastitis. Vet. Microbiol., v.106, p.61-71, 2005.

NEDER, V.E.; CANAVESIO, V.R.; CALVINHO, L.F. Presence of enterotoxigenic Staphylococcus aureus in bulk tank milk from Argentine dairy farms. Rev. Argent. Microbiol., v.43, p.104-106, 2011.

NIGHTINGALE， K.K.; SCHUKKEN, Y.H.; NIGHTINGALE, C.R. et al. Ecology and transmission of Listeria monocytogenes infecting ruminants and in the farm environment. Appl. Environ. Microbiol., v.70, p.4458-4467, 2004. 
NG, D.L.K.; TAY, L. Enterotoxigenic strains of coagulase-positive Staphylococcus aureus in drinks and ready-to-eat foods. Food Microbiol., v.10, p.317-320, 1993.

OLIVEIRA, S.S.; POVOA, D.C.; NASCIMENTO, J.S. et al. Antimicrobial substances produced by Staphylococcus aureus strains isolated from cattle in Brazil. Lett. Appl. Microbiol., v.27, p.229-234, 1998.

PELES, F.M.; VARGA, W.L.; HEIN, I.P. et al. Characterization of Staphylococcus aureus strains isolated from bovine milk in Hungary. Int. J. Food Microbiol., v.118, p.186-193, 2007.

ROBBINS, R.; GOULD, S.; BERGDOLL, M. Detecting the enterotoxigenicity of Staphylococcus aureus strains. Appl. Microbiol., v.28, p.946-950, 1974.

ROBERT, J.; TRISTAN, A.; CAVALIÉ, L. et al. Panton-valentine zleukocidin-positive and toxic shock syndrome toxin 1-positive methicillinresistant Staphylococcus aureus: a french multicenter prospective study in 2008. Antimicrob. Agents Chemother., v.55, p.17341739, 2011.

SCHUKKEN, Y.H.; GONZALEZ, R.N.; TIKOFSKY, L.L. et al. CNS mastitis: nothing to worry about? Vet. Microbiol., v.134, p.9-14, 2009.

SRINIVASAN, V.; SAWANT, A.A.; GILLESPIE, B.E. et al. Prevalence of enterotoxin and toxic shock syndrome toxin genes in Staphylococcus aureus isolated from milk of cows with mastitis. Foodborne Pathog. Dis., v.3, p.274-83, 2006.
TASCI, F.; SAHINDOKUYUCU, F.; OZTURK, D. Detection of Staphylococcus species and staphylococcal enterotoxins by ELISA in ice cream and cheese consumed in Burdur Province. African J. Agricul. Res., v.6, p.937-942, 2011.

TAKEUCHI, S.; ISHIGURO, K.; IKEGAMI, M. Production of toxic shock syndrome toxin by Staphylococcus aureus isolated from mastitic cow's milk and farm bulk milk. Vet. Microbiol., v.59, p.251-258, 1998 .

THE EFSA JOURNAL. Scientific Opinion of the Panel on Biological Hazards on a request from the European Commission on Assessment of the Public Health significance of meticillin resistant Staphylococcus aureus (MRSA) in animals and foods., v.993, p.1-73, 2009.

VERLUYTEN, J.; MESSENS, W.; DE VUYST, L. Sodium chloride reduces production of curvacin A, a bacteriocin produced by Lactobacillus curvatus strain LTH 1174, originating from fermented sausage. Appl. Environ. Microbiol., v.70, p.2271-2278, 2004.

WALSTAD, D.L.; REITZ, R.C.; SPARLING, P.F. Growth inhibition among strains of Neisseria gonorrhoeae due to production of inhibitory free fatty acids and lysophosphatidylethanolamine: absence of bacteriocins. Infect. Immun., v.10, p.481-488, 1974.

ZSCHOCK, M.; RISSE, K.; SOMMERHAUSER, J. Occurrence and clonal relatedness of sec/tst-gene positive Staphylococcus aureus isolates of quartermilk samples of cows suffering from mastitis. Lett. Appl. Microbiol., v.38, p.493-498, 2004. 